\title{
Implementation of Task-based Learning in Teaching English in Indonesia: Benefits and Problems
}

\author{
Muhammad Badrus Sholeh \\ Universitas Negeri Makassar, Indonesia \\ Email: badrus2011@gmail.com
}

DOI https://doi.org/10.15294/lc.v15i1.26004

Submitted 1 September 2020. Revised 30 September 2020. Accepted 18 October 2020

\begin{abstract}
A variety of approaches exist in foreign language teaching and learning; Task-based Learning (TBL) is one of them. It is an innovative approach that is developed from the Communicative Approach. The concepts of TBL have proven successful in classrooms. In this study, the writer conducted a literature review of task-based learning in teaching English dealing with the benefits and problems in implementing this approach in Indonesia. This paper seeks to review Task-based Learning (TBL), covering the definition of 'task' and Task-based Learning (TBL), the characteristics and stages of TBL, the teacher and students' roles in Task-based Learning, and also the advantages and disadvantages of Task-based Learning. It also addresses the application, the benefits and problems of Task-based Learning in the sense of Indonesian EFL context. This will help educators and language teachers in Indonesia to attach more importance to the contextual differences when applying Task-based Learning in Indonesia.
\end{abstract}

Keywords: task-based learning; teaching English; Indonesia; benefits; problems

\section{INTRODUCTION}

Appropriate teaching methods influence successful learning in foreign languages. The $20^{\text {th }}$ century saw a series of approaches and methods, such as the Grammar-Translation Method, Direct Method, Communicative Approach, etc. Such methodologies and methods have variously influenced the teaching of foreign languages. Task-based Learning (TBL) started to gain a growing interest in the late $20^{\text {th }}$ century to promote communicative skills growth. Some contemporary work, such as the studies by Long and Crookes (1991), and Skehan and Foster (1999), also reflect Task-based Learning's focus. Task-based learning (TBL) aims at using authentic language across practical activities. This approach promotes meaningful and student-centered communication. Students can use terms in their tasks freely and creatively.

Prabhu (1987) first introduced the idea of TBL in his Bangalore project that centered on communication through the participation of students in doing "task." They were provided clearly with a set of problems and information/opinion gaps addressed through the English medium under the guidance of teachers. Prabhu said that the focus of language was inhibiting language lear- ning. Language development has been seen as a result of natural processes. Tasks are done daily, such as writing a letter or reporting or talking to someone over the phone. TBL seeks to develop inter-language students through the provision of a task and, after that, language to solve it (Skehan, 1998). TBL tasks enable students to engage and improve their language skills considerably. Tasks assisted in Task-based Learning are seen as resources that teachers and learners can use to meet clear language goals and objectives (Samuda and Bygate, 2008).

This approach encourages the actual use of language, which facilitates the effective integration of skills. Nunan (1999) endorsed this concept by explaining that TBL requires listening, speaking, reading, and writing to complete the question presented by the same exercise challenge. As a result, TBL facilitates and encourages incorporating skills by undertaking daily-life activities that develop communicative skills for students as it provides students the chance to learn the language target continuously. Students see learning as a way to explore constructive class activities that establish real dialogue in which problems are solved, and ingenuity displayed. Implementing this approach in class typically leads to real-life activities that allow all the language skills to be 
practiced. It helps students discover various communicative opportunities inside and outside the classroom that support language practice by performing near or related activities to everyday life. Students play central roles in Task-based Learning. They have the amount of opportunity and duty to negotiate course content, select language forms from his / her linguistic repertoire, and explore different options for task performance and task results (Breen \& Candlin, 1980). Taskbased Learning incorporates the best ideas from communication language instruction to shift the traditional learning method, where students may not have learned to communicate. It establishes a specific language use objective and provides a natural language analysis context. Tasks in language classrooms are a central component of Task-based Learning because they provide a framework that stimulates learning processes and facilitates second language acquisition. Consequently, one of the factors determining the task's complexity will be the cognitive demands placed upon the learner in a task-based approach (Robinson, 2001).

The paper seeks first to review Task-based Learning literature on the concept of Task-based Learning (TBL), the characteristics and stages of TBL, teacher and student roles in Task-based Learning, and the advantages and disadvantages of Task-based Learning. It also discusses the implementation, benefits and problmes of Taskbased Learning in the Indonesian EFL context.

\section{METHODS}

This is a literature review focusing on the concepts of Task-based Learning and the implementations of this approach in Indonesian context. It also discuss the benefits and problems of implementing TBL in Indonesia. This librarybased research reviewed some studies, researches, or literatures including books and peer-reviewed journal articles. The searched databases included ERIC, Wiley Online Library, Oxford Academic, Researchgate, Semantic Scholar, Google Scholar, Global Research \& Development Services, CiteSeerX and Academia. Keyword searches were carried out using the following combinations: task-based, task-based learning, TBL, TBI, TBLT, ESL, EFL, ELT, and language acquisition. Following this, more content was checked for reference lists.

\section{RESULT AND DISCUSSION}

Definition of Task-based Learning (TBL)
Nunan (2004) describes tasks as activities that can stand alone as fundamental units and involve authentic language comprehension, manipulation, or interaction while emphasizing meanings rather than forms. Tasks provide the necessary exposure and language usage opportunities needed to acquire the target language because the tasks are typically performed in pairs or groups. Exposure occurs when students listen to the teacher's instruction, to the speech of their friends, and when they have to read hand-outs to complete the tasks. When learners have to communicate, they will acquire the language faster and more efficiently (Willis, 1996). Meanwhile, Harmer (1998: 71) said Task-based Learning puts the focus of learning on the progress of specific tasks. Task-based Learning is an approach aimed at encouraging students to act at their speed and for processing and reorganizing their inter-language within their degree and field of interest.

Richards and Rodgers (2001: 223) identify Task-based Learning as an approach that focused on using tasks as the center planning units and language teaching. TBL is a framework for language teaching that concentrated on the students' allocated tasks. It is the focal point of language teaching activities that tasks are given. Generally, Students' tasks can be assumed to be TBL's basic principles. For this situation, however, the students' task toward the beginning of the material/ meeting turns into this approach's sign. When a new type of material is given, the teacher can create a great deal of elaboration from various interactions that teachers sometimes insert an idea in the students' minds. In TBL, students will be expected to get a handle on the information to be transmitted initially in any case. Afterward, the teacher's draft will be restricted to false or true conclusions or maybe pure improvement. This approach will more enhance the role of teachers as supervisors.

From the definitions above, it could be inferred that Task-based Learning is an approach that expects students to execute the task and utilize the task as the basis of unit preparation, preparing and executing practical activities that are essential to the learning process. Task-based Learning promotes the role of tasks as a significant element of the language classroom, as it gives a superior explanation for initiating learner acquisition processes and encouraging foreign language learning. Hence, TBL depends on a language learning theory rather than a language structure theory.

The objective of Task-based Learning is to enhance the activities of language students rather 
than the activities of teachers. It is up to the teacher to perform various tasks that help learners experience the target language spontaneously, individually, and initially (Willis, 1996: 25). Each task will give students new personal knowledge of the target language, and at this point, the teacher plays a significant role. The teacher must be responsible for the awareness-raising process that must be followed by the experimental task.

Simple pair work and group work are frequently used in Task-based Learning to promote student engagement and collaboration. Even more formal cooperative learning models can be used in Task-based Learning. Task-based Learning applies to all levels of language ability, but the activity's essence varies from level to level. Another essential feature of Task-based Learning is that it is not intended to dictate or control the learners' language forms. However, as they talk, learners will make some mistakes, but they must see their mistakes as a nominal part of learning. Learners must feel free to experiment for themselves and risk-taking with the target language. Therefore, the teacher should encourage them not to say anything but to take the risk of doing something wrong.

\section{Characteristics of Task-based Learning}

Swan (2005) proposes the following Taskbased Learning characteristics: Real-World Language. Task-based Learning (TBL) is a teaching approach that fundamentally handles language as a communication device instead of a study or subject. TBL relies on real-world language use. It underscores the activities of the real world. It means that TBL concentrates on communication and interaction between the students who perform the task at the correct time using the appropriate language. Task-based Learning also offers students chances to talk in the target language and also the opportunity to rehearse the language before using it outside the classroom in a real circumstance.

Learner-Centered. TBL allows the teaching-learning cycle to be more learner-centered. The teacher opens up the possibility for the students to prepare and track their own learning by utilizing task as the essential unit of learning. It is up to the teacher to create and give various tasks that will allow the students to practice the foreign language naturally, independently, and originally.

Focus on Meaning. Task-based Learning is an approach that emphasizes on meaning rather than form. That is, instead of doing discrete form-based exercises, students perform a group of communication tasks. Students are encoura- ged to convey their thoughts on the lesson's theme, both orally and written. Such ideas should be the basis of a meaning analysis from a communication operation.

Completion of Task. Task-based Learning lets students to complete a task. The emphasis of the classroom activities is the task. Language is the tool that students use to achieve to accomplish the task. The task is an activity that uses language to get a specific result.

Besides, Nunan (2004) proposes the following 8 Task-based Learning principles: Scaffolding: Students should get support from the lessons and materials. Task chains: Every activity and task will build on the previous task. Recycling: The language recycling will maximize the learning opportunities. Organic learning: Language skills gradually "grow." Active learning: Students learn best through the constructive use of the language they are using. In other words, they learn by doing. Integration: The teachers will explain the grammatical structure and how to the fabric for communication purposes. Reflection: Students should have the ability to reflect on what they know and how well they do. Copying to creation: Students should not only learn and practice what was written for them, but they should also be able to use their imagination and creativity to solve real-world problems.

\section{Stages of Task-based Learning}

Task-based Learning provides teachers an alternate teaching approach. The teacher does not describe which language to study in a task-based lesson. The lesson is based on a specific task being performed. The language being learned is decided at the same time because the students accomplish the task. Frost (2004) reveals the following stages:

Pre-task. Teachers start the topic and provide detailed guidance to the students about what to do at the task level, and may support the students remember some vocabulary that may be helpful for doing the task.. Pre-task stage can involve playing a video of people doing the task. It offers students a detailed outline of what to expect. The students should set aside notes and require the effort to plan for the task. Ellis (2006) notes that the initial step are to pre-task the different activities that teachers and students may conduct before beginning the task. The pre-task method aims to train students to fulfill the task of promoting learning.

Task. The students do a task in pairs or groups while the teacher supervises and provide guidance. The second steps include a conversatio- 
nal lecture, mainly in nature, and offers opportunities for risk-taking students. The next step in this phase involves common expectations and successful scaffolding for the learners' communication activities.

Planning. Students formulate an oral or written report to explain what occurred in their task. Instead, in their classes, they practice what they would say. Meanwhile, the teacher is available to ask students for recommendations to clarify their language issues.

Report. After that, students present orally or read the written report back to class. The teachers choose the order of when the students should present their reports and may provide some immediate feedback about the material to the students. The teachers can also play a recording at this point in performing the same activity to compare the students. This process has some pedagogical objectives, such as providing consistent task results, promoting reflection on how the task was done, and finally promoting disturbing ways in the learner's task.

Analysis. Then, the teacher points out the important components of the recording text for review by the students. They can be asked to note fascinating characteristics in this text. The teacher may also illustrate the vocabulary used for the student's interpretation during the study process.

Practice. Finally, the teacher chooses language fields to learn depending on the students' needs and what resulted from the phases of the challenge and study. Students then conduct activities to boost their self-confidence and valuable language notes.

\section{Teacher and Students Roles in Task-based Learning}

Richards and Rodgers (2001) suggest that the creation of classroom interaction is the responsibility of both teachers and students in Taskbased Learning. Within a Task-based Learning, teachers and students' positions change as collaborative research TBL approaches learning and teaching. Through Task-based Learning, students and teachers have specific responsibilities. Richards and Rogers (2001) discuss the teachers and the student's roles in Task-based Learning, while far from being comprehensive.

Three main roles should be played by teachers implementing Task-based Learning in the foreign language classroom: Selector and sequencer of tasks: teachers have an important function in choosing, chancing, and making tasks and afterward shaping them according to students' needs, interests, and language skills. Getting ready students for tasks: some pre-task preparation is significant for students. Such preparing activities can include introducing subjects, explaining task directions, helping students learn or remembering valuable words and phrases to promote the task easy to complete, and fractional presentation of the task process. Awareness-raising: the teacher utilizes a combination of shape-focusing strategies that incorporate care-focusing pre-task practices, the review of the provided text, controlled access to parallel tasks, and the utilization of featured materials.

While students in the foreign language classroom who incorporate Task-based Learning will play three key roles: Participant group: students perform several duties in pairs or small groups. For students who are increasingly acclimated with full-class activities and/or individual work, pair or group work can need some adjustment. Monitor: the tasks used in Task-based Learning are to promote learning. Classroom activities will help students learn how to use communication language. Students must "attend" the message in task work, yet in addition how normally such messages are stuffed. Risk-takers and innovators: several tasks allow students to generate and interpret messages lacking complete linguistic resources and previous experience. The purpose of these tasks is said to be this. Students will need to acquire the abilities to guess from linguistic and contextual hints, ask for clarity, and communicate with other students.

\section{Advantages and Disadvantages of Task-based Learning}

Some experts have suggested some of the advantages of Task-based Learning, so the teachers can use them to enforce it. Firstly, Task-based Learning offers a clear setting for the use of language. The ordinary meaning can be achieved by providing a variety of tasks to the students. Hence the students directly study the language. The students must work together to complete the assignment assigned to the instructor. In a natural context, students have many opportunities to learn a language (Larsen, 2000:144). Second, Task-based Learning is student-centered. The teacher should only present the word in pre-task according to the teaching procedures in TBL. In the work cycle and language orientation, students may then use their language. It leads the students to become active learners.

Nevertheless, they track the students even while they do the job (Willis, 2006). Thirdly, the students participate in Task-based Learning. Therefore they are more likely to be associated with 
learning the target language (Willis, 2006). The teacher may use them as guides to choose Taskbased Learning to teach English according to some of the advantages listed above.

In addition to some advantages, Taskbased Learning also has weaknesses or disadvantages. Because there are many learning activities using Task-based Learning, students also spend plenty of time. The teacher would say this if they are going to apply Task-based Learning. Another disadvantage is that the teacher should clarify the task at the pre-task stage, so he or she has limited time to use the language or provide a role model.

\section{Implementation of Task-based Learning in Teaching English in Indonesia}

Several researches have been conducted in Indonesia on Task-based Learning. These studies primarily analysed the application of TBL on a tertiary level and in public school classrooms. They highlighted the factors that restricted TBL's introduction in classes, including the confidence of teachers and other contextual factors in Indonesia, such as the English exams program, availability of resources, students ' different needs, and language skills levels.

Hutagulung (2004) performed the first empirical analysis. In her work, she used a descriptive qualitative design. It was also announced that Task-based Learning implementation runs effectively and adequately to Junior High School at the first-grade level. It shows that Task-based Learning is being introduced in Indonesia in many English classrooms. The English teacher of SMP Negeri 28 Surabaya is one of the teachers who introduce Task-based Learning. Wisnu did a research in 2006. A vocational high school in Cimahi, West Java, undertook this research. It attempted to see the potential application in a local context of Task-based Learning in teaching speaking. This research also attempted to evaluate factors leading to the instruction implementation and clarify the importance of using qualitative data in exploring TBL implementation. It was stated in this study that TBL may be applied when the instructor (1) adjusts different task cycles; (2) prolongs other task cycles; and (3) adopts specific language teaching methodologies in the TBI setting.

The next research is carried out in SMAN 5 Bandarlampung by Desmayenni (2012). This research aimed to find out whether Task-based Learning (TBL) increases students' participation during the process of teaching and learning and the descriptive writing ability of students at SMAN 5 Bandarlampung's first year students.
The qualitative data was used by questionnaire and observation sheet to see students 'involvement during the learning process. Meanwhile, quantitative data was used to know the students' ability to write descriptive text as the learning tool through the score of students. The first-year Action Research (CAR) was done in two stages. Ideally, if the teacher is actively engaged in the teaching-learning process with at least 75 percent of students and 75 percent of students, the indicators of this research success will earn 70 or more or better. It can be said that during the teaching learning process, TBL will increase students' participation and the descriptive text writing skills of students.

The next study was conducted by Zahro (2005). The study's research question is "How can Task-based Learning enhance reading understanding of students at IBB 10th at the SMA Muhammadiyah 2 Gentengteaching-learning year 2014/2015?". And the research question aims to see how Task-based Learning can increase the understanding of reading among students. Taskbased Learning has been applied in small groups or pairs in teaching and learning, 69,4 percent (20 students) in cycle 1 and 88 percent (26 students) in cycle 2 . Task-based Learning has improved student comprehension in two cycles from the average student ratings (61.3) in cycle 1 to (72) in cycle 2 . Based on the research findings, task-based education will help enhance students' understanding of reading in the SMA Muhammadiyah 2 Genteng academic year 2014-2015.

Besides, a study was performed by Simamora (2018). In this work, the researcher used quantitative research methods because TBLT will enhance the student's ability to write a descriptive text. The study was designed in two groups before the post-test phase. Besides, the results indicated that there are significant differences between the pre- and post-test approaches and that the student writing ability was developed efficiently. The results from the research show that $t$-value was 6,441 ; the t-table is at least 2,145 and $0,00<0,05$. The null hypothesis is therefore dismissed for the experiment, and the test hypothesis is accepted. In short, TBLT can enhance the student's writing ability.

Task-based Learning is also explored through listening skills. A study was carried out by Arnoi (2018). The study aimed to determine the effect on the listening output of the first grade of SMA Al-Kautsar Bandar Lampung of the Task-Based Language Teaching (TBLT). This research was carried out using a quantitative methodology using a single pre-test design. Research 
findings found that there has been a statistically significant improvement in the listening performance of students at first-grade SMA Al-Kautsar Bandar Lampung with a sense level of 0.05 after being educated in Task-based Language Teaching (TBLT). The statistical result has shown that the $\mathrm{t}$-value (9.523) was higher than the t-table (2.045), and the meaning value (0.00) was lower than (0.05). From the above findings, it may be inferred that TBLT has a positive influence on students' listening performance.

These studies indicate that TBL, given its positive effect, primarily has on schools in Indonesia's teaching and learning sense of foreign languages. The research discussed in this article thus contributes to TBL literature in Indonesian contexts.

\section{Benefits of Task-based Learning in Teaching English in Indonesia}

Task-based Learning provides many benefits as it is communication-based, allowing previously acquired information to be passed to current communicative contexts (Nunan, 2004). It aims to engage learners in practical language usage (Ellis, 2009).

Task-based Learning makes students connect precipitously. The students are allowed to use any vocabulary and grammar they learn. For example, a role-play needs the student openly uses words. It gives students the opportunity to evaluate their vocabulary. It additionally allows students to learn and benefit from certain words, thereby increasing their trust level. The cognitive ability and communication skills of the learners are established in the course of a task. Students' attention is based on problem-solving rather than on individual language systems. It inspires more motivated students.

Automaticity. Automation for language learning is intended to improve efficiency, accuracy, and stability. (Rider I.et al, 2007). It is additionally recommended that automaticity is almost indigenous. Research into cognitive psychology and acquisition of second language indicates that automaticity is accomplished in an authentic communication situation using creative language rules (Rider et al, 2007). Learning based on assignments makes ready for automaticity. Cognitive language theories recommend that real-life learning situations are useful for automatic language knowledge (Ellis, 2009).

Task-based learning allows language learners to master vocabulary. In general, teachers are responsible for teaching, and students do not participate. Words that are taught are quickly forgotten, and when the teacher considers creativity to involve students in the pre-task, it's beneficial to students. The alternatives suggested to increase vocabulary include predicting title- or subject-related terms and creating terms in a web word through brainstorm, cooperative dictionary search, and matching words with a meaning list (Newton, 2001). In the course of the assignment, it is found that a glossary allows the learner to acquire vocabulary, so these words are not preserved, but words extracted from active processing have been learned better (Newton, 2001). A better interactive glossary is helpful than a standard glossary. Interactive glossary is the place where students communicate. The instructor must make additional efforts to create an engaging glossary. It is also worth encouraging students to negotiate new definitions rather than relying on external sources. While the issue of vocabulary quality acquired through group work persists, learners make impressive progress. Vocabulary preparation is also said to occur naturally when students participate in collective task-based experiences. Completing the task if students are motivated to document new terms and rewrite them and if the original words are evaluated in various meanings and ways to boost their language comprehension. The teacher must guarantee that students can meet and investigate new vocabulary without direct teachers' assistance through training and use this vocabulary to accomplish significant task objectives (Newton, 2001).

Language learning does not take place without the knowledge of encouragement and language resources. Task-based Learning forces students to utilize language in an engaged and community way. Students can discuss it turns to talk and also evaluate diverse correspondence methodologies. Task-based Learning makes conditions that naturally improve language learning. It gets ready for students to utilize their language in the real world.

Maximizes the communication scope. Taskbased Learning offers students the conditions to acclimatize what they feel and comprehend when carrying out the task. By completing the challenge, students buy new language items and use the language they have recently purchased. Tasks empower students to learn and acclimatize language components they effectively perceive and comprehend. They allow students to create their recently gained knowledge into new communications contexts creatively. They involve students in purposeful communication and provide students with opportunities to test diverse communication methods and equip them with vocabulary for 
their public use.

Experiential learning. Experiential learning will build a critical conceptual foundation for Task-based Learning. The imminent personal knowledge of the students is the starting point for this approach. Intellectual development is claimed as students take part and focus on the task sequences. Active participation is viewed as fundamental to this approach; therefore, it centers on learners. This goes against the method of transmitting information in which the students passively gain teacher awareness. Experiential learning has different origins in various fields. Psychologist David Kolbe has brought together multiple aspects of social psychology, humanist education, developmental education, and cognitive theory (Nunan, 2004).

\section{Problems of Implementing Task-based Learn- ing in Teaching English in Indonesia}

While Task-based Learning can lead to effective teaching-learning in Indonesia's EFL classroom, some school settings may still be some issues (Ismail, 2017). They are defined as follows:

Teachers with Limited Language Proficien$c y$. When teachers want to integrate Task-based Learning in the EFL classroom, they should have sufficient language skills to guide and model student learning. Or on the other hand, they can have adequate language instruction to promote student language acquisition. Going to professional workshops or language events may help inspire teachers to develop their language skills.

Inadequate teacher training in TBL methodolo$g y$. It could be an issue unless teachers are trained in Task-based Learning. In this case, teachers should follow TBL-designed textbook materials as it could be a simple route for teachers to figure out how to framework students adequately. Therefore, teachers must offer sufficient in-service training for teachers to rehearse TBL in their classrooms. Finally, teachers could join some development workshops in TBL aimed at gaining TBL professional knowledge. Teachers will feel more confident in implementing TBL in the teaching and learning process.

Traditional Examination-Based Syllabi. $\mathrm{Nu}-$ merous teachers are worried that TBL would sabotage students' opportunity of success in conventional examinations, particularly if they put more emphasis on grammar and consistency than on the ability to communicate appropriately. School tests or outer open tests are often essential motivators for students to study a language. Everything that does not directly relate to them is also considered a waste of time. If their tests do not assess oral communication, students frequently worry about the importance of oral participation.

Lack of Sufficient Resources. Resources can allude to time, location, technology tools, TBL supplementary materials, and so on. A few schools in rural areas, for instance, might not have the internet in the classroom. Therefore, teachers should consider these confinements when planning task-based lessons.

Linguistic insufficiency. Students who are beginners without linguistic resources find taking part in a challenge very challenging. It may be incredibly difficult and strenuous to continue the conversation while speaking about activities such as role-play or explaining the discrepancies learners can consider. They may not understand what the task needs and may find it difficult to be understood in the task. Students may eventually be unmotivated to do the task and will lose their self-confidence.

Various and different classes. A class of students with varying skills, styles of learning, and levels of motivation. Thus, the tasks endorsed might apply to a few students, and it might be so challenging for others, and it might be so simple for some others, and they might believe it is spending a lot of time to do the task. At the same time, it isn't easy to account for learners with specific previous knowledge levels. Students with insufficient knowledge may seem that the tasks so challenging, and high-understanding learners will find the tasks too straightforward and tedious simultaneously.

Large Class Sizes. Learning and teaching based on tasks may need some additional time to complete the tasks. In addition to big class size issues, teachers may not have sufficient opportunity to deal with each student and track their learning procedure or progress. In answer, teachers may pick and train some significant -level students. We will help other students teach, or model target skills and learn informative abilities all alone.

Class Room Condition. Suppose the classroom used in implementing Task-based Learning is too cramped (uncomfortable, overcrowded). In that case, the teachers should adjust the classroom or reduce energetic activity among the changes you need.

\section{CONCLUSION}

With a view of the theoretical context and practical aspect of Task-based Learning, it appears that TBL is better than the conventional teaching approach because students are involved 
in the communicative classroom. The students can be shifted from passive to active using TBL implementation. Students will have the opportunity to learn a specific language with authentic materials. The language skills and communication skills of the learner will be built through taskbased learning. TBL can help language students use their language skills to communicate their meaning fluently and accurately in a long-term project. Briefly, the TBL looks like a realistic approach to encouraging foreign language learning among L2 learners and improving their language skills and communication skills. It is recognized that it would be difficult and risky for teachers in a foreign language classroom to apply TBL, particularly in the secondary school context effectively. Nevertheless, its advantages could well outweigh its disadvantages.

In the background of Indonesian EFL, where there is little or no practical use of English outside the classroom, many students study English as a subject, not as a functional language, and their target is to achieve high scores in highstakes testing. This condition seems to be incompatible with the communicative practices carried out in TBL. The pedagogical benefits of TBL are numerous: (1) helping learners to interact spontaneously, (2) leading automaticity, (3) giving language learners opportunity to learn vocabulary, (4) providing necessary conditions for language learning, (5) maximizing scope for communication, and (5) providing experiential learning. There are also many problems in implementing TBL in the Indonesian EFL context, such as teachers with limited language proficiency, inadequate teacher training in TBL methodology, traditional examination-based Syllabi, lack of appropriate resources, linguistic deficiency, and diverse classes, large class sizes, and classroom condition. Task-based learning would be more feasible and effective if it can be modified to be a context-sensitive teaching method, teacher interests, values, and experiences align better with TBL concepts.

\section{REFERENCES}

Arnoi, K. N. (2018). Teaching Listening Through Task Based Language Teaching in Descriptive Text at The First Grade of SMA Al-Kautsar

Breen, M., \& Candlin, C. N. (1980). The essentials of a communicative curriculum in language teaching. Applied Linguistics, 1, 89-112.

Desmayenni, M. (2012). Implementation of Task-Based Learning Method in Writing Descriptive Text. FKIP Unila.

Ellis, R. (2003). Task-based language learning and teaching. Oxford University Press.
Ellis, R. (2006). Current issues in the teaching of grammar: An SLA perspective. TESOL Quarterly. 40(1), 83-107.

Ellis, R. (2009). Task-based language teaching: sorting out the misunderstandings. International Journal of Applied Linguistics, 19(3), 221-246.

Frost, R. (2004). A Task-based Approach. On line Documents at http://www.teachin5.genglish. org.uk/think/methodology/task_based.shtml. [26.06.2020]

Harmer, J. (1998). How to teach English: An introduction to the practice of English Language Teaching. Longman.

Hutagalung, E.Y. (2004). The implementation of Task Based Language Teaching in teaching Descriptive Text to the First Graders of junior high school, 2.

Ismail, M.A. (2017). Revisiting the implementation of task-based language teaching (TBLT) in Indonesian secondary school: Current issues and possibilities. PEOPLE: International Journal of Social Sciences, 3(3), 601-612.

Jeon, I.J., \& Hahn, J.W. (2006). Exploring EFL teachers? Perceptions of task-based language teaching: a case study of Korean secondary school classroom practice. Asian EFL Journal, 8, 123 -139 .

Larsen-Freeman, D. (2000). Techniques and Principles in Language Teaching. Oxford University Press.

Long, M., \& Crookes, G. (1991). Three approaches to task-based syllabus design. TESOL Quarterly, 26(1), 27-56.

Newton, J. (2001). Options for vocabulary learning through communication tasks. ELT Journal, 55(1), 30-37.

Nunan, D. (1989). Designing Tasks for the Communicative Classroom. Cambridge University Press.

Nunan, D.. (2004). Task-based language teaching. Cambridge University Press.

Prabhu, N. S. (1987). Second Language Pedagogy. Oxford University Press.

Richards, J. C., \& Rodgers, T. S. (2001). Approaches and methods in language teaching (2nd ed.). Cambridge University Press.

Ridder, I., Vangehuchten, L., \& Gomez, M. (2007). Enhancing automaticity through task-based language teaching. Applied Linguistics, 28(2), 309-315.

Robinson, P. (2001). Task complexity, task difficulty, and task production: Exploring interactions in a componential framework. Applied Linguistics, 22(1), 27-57.

Samuda, V., \& Bygate, M. (2008). Tasks in Second Language Learning. Palgrave MacMillan.

Simamora, Ricky O. (2018). The Implementation of Task-Based Language Teaching to Improve Students' Writing Ability at the Third Grade of SMP Widya Dharma Bandar Lampung. Skipsi. Lampung University.

Skehan, P. (1998). A cognitive approach to language learning. Oxford University Press.

Skehan, P., \& Foster, P. (1999). The influence of task 
Language Circle: Journal of Language and Literature 15 (1) October 2020 1-9

structure and processing conditions on narrative retellings. Language Learning, 49(1), 93-120.

Swan, M. (2005). Legislation by hypothesis: The case of task-based instruction. Applied Linguistics, 26(3), 376-401.

Willis, J. (1996). A Framework for Task-Based Learning. Longman.

Willis, J. (2006). Research-based strategies to ignite student learning: Insights from a neurologist/classroom teacher. ASCD.
Wisnu, H. (2006). The implementation of task-based instruction in teaching speaking. Thesis. Sanata Dharma University.

Zahro, F. (2015). The Implementation of Task-Based Learning to Improve the Tenth Grade Students' reading Comprehension of SMA Muhammadiyah 2 Genteng in the 2014/2015 Academic Year. Unpublished Thesis. University of Muhammadiyah Jember. 